\title{
Mapping of Fluoride Endemic Areas in Rae Bareli District, Uttar Pradesh, India
}

\author{
SUDHANSHU KANAUJIA $^{* a, b}$, BHARAT SINGH $^{\mathrm{a}}$ and SANJAY KUMAR SINGH ${ }^{\mathrm{b}}$ \\ ${ }^{a}$ Department of Chemistry, University of Allahabad, Allahabad, U.P- 211004, India \\ ${ }^{\mathrm{b}}$ Department of Chemistry, Institute of Engineering and Technology, \\ Lucknow, U. P., 226021, India \\ sh.sudhanshu@gmail.com
}

Received 27 January 2013 / Accepted 16 February 2013

\begin{abstract}
The objective of this study is to mapping of fluoride endemic areas of main blocks of Rae Bareli district, India. The fluoride level in drinking water is estimated through fluoride ion selective electrode method. Google earth and isopleths technique were used for mapping of fluoride endemic areas. From the study, it is observed that Dalmau and Amawa blocks of Rae Bareli district in Uttar Pradesh are highly fluoride endemic. About $80 \%$ of villages in these blocks have fluoride level more than the prescribed permissible limit in drinking water. Due to fluorosis, health risks in Dalmau and Amawa blocks have become evident. From the results, the people in Dalmau and Amawa blocks are advised to consume drinking water with fluoride level less than $1 \mathrm{mg} / \mathrm{L}$. It has been recommended to the government authorities to take serious steps in supplying drinking water with low fluoride concentration for the fluoride affected villages.
\end{abstract}

Keywords: Groundwater, Endemic fluorosis, Ion selective electrode, Rae Bareli

\section{Introduction}

Fluoride is widely dispersed in nature and is estimated to be the $13^{\text {th }}$ most abundant element on our planet ${ }^{1}$. Fluoride ion in drinking water is known for both beneficial and detrimental effects on health. The World Health Organization and Indian Council of Medical Research described the drinking water quality guideline value $\mathrm{e}^{2-3}$ for fluoride is $1.5 \mathrm{mg} / \mathrm{L}$. Abnormal level of fluoride in water is common in fractured hard rock zone with pegmatite veins ${ }^{4}$. Fluoride ions from these minerals leach into the groundwater and contribute to high fluoride concentrations ${ }^{5-7}$. The prevalence of fluorosis is mainly due to the intake of large quantities of fluoride through drinking water is reported in many states of India ${ }^{8-12}$. The bioavailability of soluble fluoride ingested with water was nearly $100 \%$, because soluble fluoride in drinking water was easily absorbed by the gastrointestinal tract without intervention of interfering elements such as $\mathrm{Ca}$, $\mathrm{Mg}$ and $\mathrm{Al}^{14-19}$. So, water fluoride level is a primary factor for the cause of fluorosis.

Fluorosis is a slow, progressive, crippling malady, which affects every organ, tissue and cell in the body and results in health complaint having overlapping manifestations with several other diseases. The primary adverse effects associated with chronic, excess fluoride intake are dental and skeletal fluorosis ${ }^{20}$. It also adversely affects the foetal cerebral function 
and neurotransmitters ${ }^{21-23}$. Reduced intelligence in children is associated with exposure to high fluoride levels in food and drinking water ${ }^{24-26}$. The global prevalence of fluorosis is reported ${ }^{27}$ to be about $32 \%$. In India, around 20 million people were severely affected by fluorosis and around 40 millions are exposed to its risk ${ }^{28}$. The number of people getting affected, the number of villages, blocks, districts and states endemic for fluorosis have been steadily increasing ever since the disease was discovered in India during 1930s. The reason for the increase in the disease incidence and the sizeable number of locations being identified as endemic zones for fluorosis is due to overgrowth of population, necessitating more and more water, indiscriminate digging of tube wells, resorting to the use of hand pump water, unawareness regarding the importance of checking water quality, specially for fluoride and due to water shortage. Agencies responsible for water supply resort to pumping water from open wells and tube wells to overhead tanks and supply groundwater to residents and invariably such sources are not tested for fluoride ${ }^{20}$.

Based on the extensively documented relationship between caries experience and both water fluoride concentration and fluoride intake, the adequate intake and recommended dietary allowance for fluoride from all sources is set at $0.05 \mathrm{mg} / \mathrm{kg} / \mathrm{day}$. This intake range is recommended for all ages greater than 6 months, because it confers a high level of protection against dental caries and is associated with no known unwanted health effects. Agencies also set the adequate intake level for infants below 6 months at $0.01 \mathrm{mg} / \mathrm{kg} / \mathrm{day}$.

Most of the people in the villages of Dalmau and Amawa blocks of Rae Bareli district (Figure 1) have severe dental fluorosis. In order to find out the extent of fluoride contamination in drinking water and to find out the fluoride exposure dose in Dalmau and Amawa blocks, an extensive study was accomplished by estimating fluoride level in drinking water. Identification of exact geographical location of high fluoride exposed area is much useful to perform remedial measures and is helpful to give awareness about fluorosis to the villagers residing in that particular area. The mapping of fluorotic areas was facilitated by using Google Earth, because it display satellite images of most inhabited regions of Earth, allowing users to visually see the exact location with geographical information.
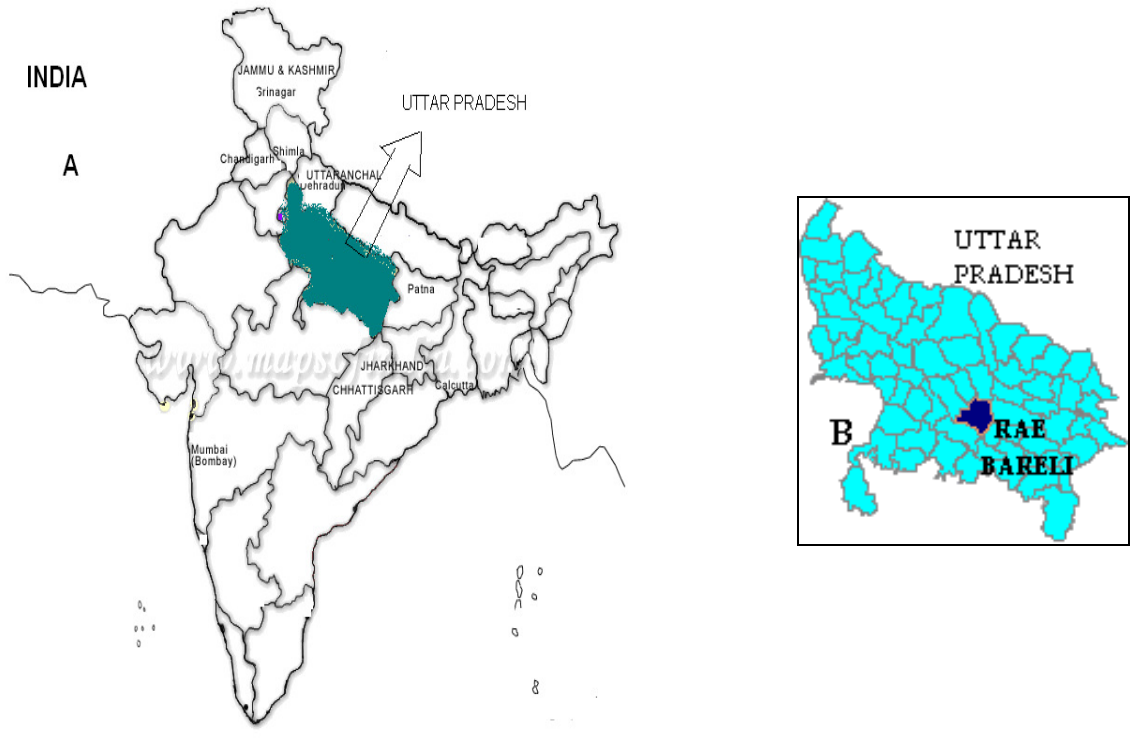

Figure 1. Location of Rae Bareli district in Uttar Pradesh, India 


\section{Experimental}

Groundwater sample were collected from tube wells and hand pumps from 5 blocks of Rae Bareli district in $500 \mathrm{~mL}$ capacity of plastic bottles, pre-washed with detergent, tap water and distilled water. One $\mathrm{mL}$ of Conc. $\mathrm{HCl}$ was added as a preservative and water was filled to the brim of the bottle without any bubbles. The water was left to run from the source for about 4 min to equate the minimum number of well volume and to stabilize the electrical conductivity ${ }^{29}$.

\section{Reagents and standards}

Analytical grade chemicals were used throughout the study without further purification. To prepare all the reagents and calibration standards, deionised water was used. Each sample was analysed thrice.

\section{Methodology}

111 samples were collected and analyzed for fluoride level, measured by fluoride ion selective electrode. This method is applicable to the measurement of fluoride in drinking water, groundwater and lightly polluted ${ }^{9}$ water in the concentration range of 0.2 to $2000 \mathrm{mg} / \mathrm{L}$. The fluoride concentration in the groundwater sample was determined directly after diluting with equal volume of total ionic strength ${ }^{10}$ adjustment buffer (TISAB) of $\mathrm{pH}$ 5.2. A buffer solution is added to the standard and sample solution to reduce matrix interferences and ionic strength effects. The instrument was calibrated with standard sodium fluoride solutions so chosen that the concentration of one was ten times the concentration of other so that the concentration of the unknown sample solution was directly read from the digital display of the meter (Figure 2).
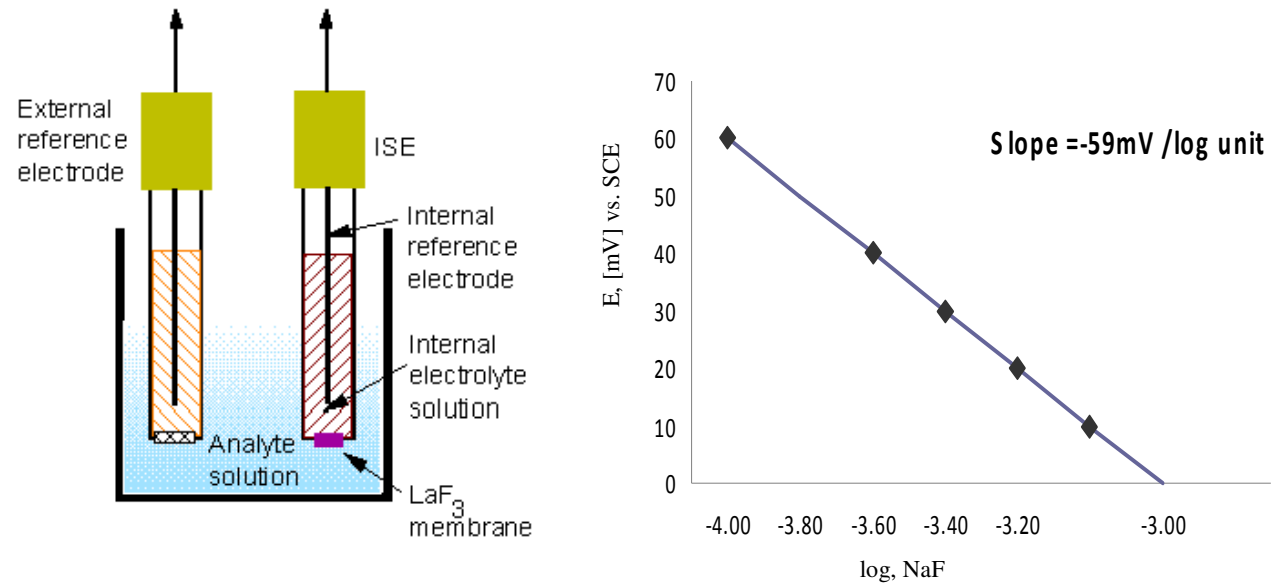

Figure 2. Fluoride ion electrode and calibration curve for fluoride concentration by ion selective electrode method

\section{Results and Discussion}

\section{Dalmau and Amawa block}

In Dalmau block, out of 30 samples around $20 \%$ of the samples had fluoride level above $3 \mathrm{mg} / \mathrm{L}, 70 \%$ of the samples contain water fluoride level between 1.5 and $3 \mathrm{mg} / \mathrm{L}$ and $10 \%$ between 1 and $1.5 \mathrm{mg} / \mathrm{L}$. The mean fluoride level of all collected sample was estimated as 2.34. Groundwater fluoride levels of Dalmau and Amawa blocks are listed in Table 1 and 2. 
Table 1. Fluoride concentration in groundwater of Dalmau block

\begin{tabular}{ccccccc}
\hline $\begin{array}{c}\text { S. } \\
\text { No. }\end{array}$ & Villages & $\begin{array}{c}\mathrm{S}_{1} \\
\mathrm{ppm}\end{array}$ & $\begin{array}{c}\mathrm{S}_{2} \\
\mathrm{ppm}\end{array}$ & $\begin{array}{c}\mathrm{S}_{3} \\
\mathrm{ppm}\end{array}$ & Mean & $\begin{array}{c}\text { Range } \\
\mathrm{ppm}\end{array}$ \\
\hline 1. & Aihar Dakauli & 3.50 & 2.95 & 3.00 & 3.15 & $2.95-3.50$ \\
2. & Bairahana & 2.10 & 1.80 & 1.65 & 1.85 & $1.65-2.10$ \\
3. & Balipur & 1.70 & 1.00 & 2.10 & 1.60 & $1.00-2.10$ \\
4. & Raudawa & 2.50 & 1.50 & 3.00 & 2.33 & $1.50-3.00$ \\
5. & Poore Dhanu & 4.00 & 3.00 & 3.50 & 3.50 & $3.00-4.00$ \\
6. & Gaura Upasi & 2.00 & 1.25 & 1.75 & 1.67 & $1.25-2.00$ \\
7. & Kuwar mau & 1.80 & 1.00 & 1.60 & 1.47 & $1.00-1.80$ \\
8. & Khalilpur & 3.05 & 2.85 & 3.10 & 3.00 & $2.85-3.10$ \\
9. & Saraikarjani & 3.10 & 2.70 & 3.00 & 2.93 & $2.70-3.10$ \\
\hline
\end{tabular}

Table 2. Fluoride concentration in groundwater of Amawa block

\begin{tabular}{ccccccc}
\hline S. No. & Villages & $\mathrm{S}_{1} \mathrm{ppm}$ & $\mathrm{S}_{2} \mathrm{ppm}$ & $\mathrm{S}_{3} \mathrm{ppm}$ & Mean & Range $\mathrm{ppm}$ \\
\hline 1. & Poore Paturia & 4.10 & 3.95 & 4.00 & 4.02 & $3.95-4.10$ \\
2. & Kachaunda & 3.00 & 2.85 & 3.20 & 3.02 & $2.85-3.20$ \\
3. & Poore Subedar & 2.10 & 2.00 & 1.94 & 2.01 & $1.94-2.10$ \\
4. & Poore Sichharia & 1.80 & 1.90 & 1.56 & 1.75 & $1.56-1.90$ \\
5. & Poore Sankaraha & 1.80 & 1.35 & 1.60 & 1.58 & $1.35-1.80$ \\
6. & Parvaiya & 2.00 & 2.00 & 1.55 & 1.85 & $1.55-2.00$ \\
7. & Khairahna-I & 1.80 & 1.40 & 1.15 & 1.45 & $1.15-1.80$ \\
8. & Kairahna-II & 1.70 & 1.54 & 1.28 & 1.51 & $1.28-1.70$ \\
9. & Poore Mota & 1.25 & 1.00 & 0.93 & 1.06 & $0.93-1.25$ \\
10. & Dusauti & 1.23 & 0.85 & 1.25 & 1.11 & $0.85-1.25$ \\
\hline
\end{tabular}

Around $13 \%$ of the samples in Amawa block have water fluoride level above $3 \mathrm{mg} / \mathrm{L}, 53 \%$ of samples have fluoride level between 1.5 and $3 \mathrm{mg} / \mathrm{L}, 27 \%$ between 1 and $1.5 \mathrm{mg} / \mathrm{L}$. The mean fluoride level of this block was found to be 1.94 .

\section{Deeh, Sadar and Unchahar block}

Out of 12 samples collected from 4 villages of Deeh block, $16 \%$ of the samples recorded fluoride above $3 \mathrm{mg} / \mathrm{L}$ whereas in $34 \%$ of the samples fluoride concentration was between 1.5 and $3 \mathrm{mg} / \mathrm{L}, 17 \%$ between 1 and $1.5 \mathrm{mg} / \mathrm{L}$ and $33 \%$ of the samples, fluoride concentration was within the limit. The mean fluoride level was found to be $1.87 \mathrm{mg} / \mathrm{L}$. In Sadar block, 24 samples were analyzed from 8 villages, only $4 \%$ samples have fluoride between 1.5 and $3 \mathrm{mg} / \mathrm{L}, 38 \%$ samples have fluoride slightly greater than $1 \mathrm{mg} / \mathrm{L}$ and $55 \%$ of the samples have fluoride concentration lesser than $1 \mathrm{mg} / \mathrm{L}$.

Total 15 samples were collected from 5 villages of Unchahar block. Among these villages, $53 \%$ groundwater samples found between 1.5 and $3 \mathrm{mg} / \mathrm{L}$ of fluoride. $20 \%$ of the samples contain fluoride between 1 and $1.5 \mathrm{mg} / \mathrm{L}$ and $27 \%$ of the samples were below $1 \mathrm{mg} / \mathrm{L}$ of fluoride level. Groundwater fluoride levels of above blocks are listed in Tables 3, 4 and 5 respectively.

Table 3. Fluoride concentration in groundwater of Deeh block

\begin{tabular}{ccccccc}
\hline S. No. & Villages & $\mathrm{S}_{1} \mathrm{ppm}$ & $\mathrm{S}_{2} \mathrm{ppm}$ & $\mathrm{S}_{3} \mathrm{ppm}$ & Mean & Range $\mathrm{ppm}$ \\
\hline 1. & Poore Narayana & 4.20 & 2.95 & 3.70 & 3.62 & $2.95-4.20$ \\
2. & Tekari & 0.90 & 0.75 & 0.80 & 0.82 & $0.75-0.90$ \\
3. & Matia Gadar & 1.60 & 1.74 & 2.20 & 1.85 & $1.60-2.20$ \\
4. & Poore Sabha & 1.25 & 0.96 & 1.30 & 1.17 & $0.96-1.30$ \\
\hline
\end{tabular}


Table 4. Fluoride concentration in groundwater of Sadar block

\begin{tabular}{ccccccc}
\hline S. No. & Villages & $\mathrm{S}_{1} \mathrm{ppm}$ & $\mathrm{S}_{2} \mathrm{ppm}$ & $\mathrm{S}_{3} \mathrm{ppm}$ & Mean & Range $\mathrm{ppm}$ \\
\hline 1. & Khamariya & 0.84 & 0.64 & 0.61 & 0.70 & $0.61-0.84$ \\
2. & Poore Kaushal & 0.54 & 0.56 & 0.45 & 0.52 & $0.45-0.56$ \\
3. & Kakraha & 0.61 & 0.50 & 0.73 & 0.61 & $0.50-0.73$ \\
4. & Barwalia & 0.86 & 1.20 & 1.00 & 1.02 & $0.86-1.20$ \\
5. & Peera Nagar & 0.95 & 1.05 & 0.88 & 0.96 & $0.88-1.05$ \\
6. & Bagaha & 1.11 & 1.23 & 0.94 & 1.09 & $0.94-1.23$ \\
7. & Matka & 1.20 & 1.05 & 0.77 & 1.01 & $0.77-1.20$ \\
8. & Thekhai & 1.40 & 1.22 & 1.76 & 1.46 & $1.22-1.76$ \\
\hline
\end{tabular}

Table 5. Fluoride concentration in groundwater of Unchahar block

\begin{tabular}{ccccccc}
\hline S.No. & Villages & $\mathrm{S}_{1} \mathrm{ppm}$ & $\mathrm{S}_{2} \mathrm{ppm}$ & $\mathrm{S}_{3} \mathrm{ppm}$ & Mean & Range $\mathrm{ppm}$ \\
\hline 1. & Paindapur & 2.50 & 2.00 & 2.00 & 2.16 & $2.00-2.50$ \\
2. & Meera shah & 1.70 & 2.25 & 2.80 & 2.25 & $1.70-2.80$ \\
3. & Poore Muraein & 2.10 & 1.70 & 1.25 & 1.68 & $1.25-2.10$ \\
4. & Sawaiya & 0.80 & 0.95 & 0.90 & 0.88 & $0.80-0.95$ \\
5. & Sabji Mandi & 1.00 & 1.25 & 0.80 & 1.02 & $0.80-1.25$ \\
\hline
\end{tabular}

This study revealed that some remote villages of Dalmau block such as Aihar Dakauli, Poore Dhanu and Khalilpur have high fluoride concentration in groundwater. The groundwater samples of these villages contain more than $3 \mathrm{mg} / \mathrm{L}$ fluoride, which is two times of the safe fluoride level in groundwater. Supply of safe drinking water to this block is a fruitful way to minimize fluorosis. Groundwater samples from Amawa block are also contaminated with excess fluoride. Poore Paturia and Kachaunda villages of this block are severely affected from fluorosis. Due to the high fluoride level in groundwater, this block is also considered as fluoride endemic area. In Amawa block, the reason for the contamination of fluoride in drinking water is due to geological conditions, as there is no canal or fluoride contaminating industry located in this block or nearby. The water samples in Deeh block have $16 \%$ of the samples with fluoride level above $3 \mathrm{mg} / \mathrm{L}$ and $34 \%$ of the samples have fluoride level between 1.5 and $3 \mathrm{mg} / \mathrm{L}$. Due to the high fluoride level of groundwater, this block is also considered as fluoride endemic area. So the people of this block are also facing the problem of fluorosis.

The water samples in other blocks studied such as Sadar and Unchahar block have 5 and $47 \%$ fluoride level between 1.5 and $3.0 \mathrm{mg} / \mathrm{L}$, hence these blocks are also considered as fluoride endemic area and water sources in these blocks are not safe for consumption. The villages and areas identified with different water fluoride levels in 5 blocks of Rae Bareli district are shown in Figure 3 which is useful for the government agency to install defluoridation plants in few villages as well as nongovernmental organizations to conduct awareness programmes.

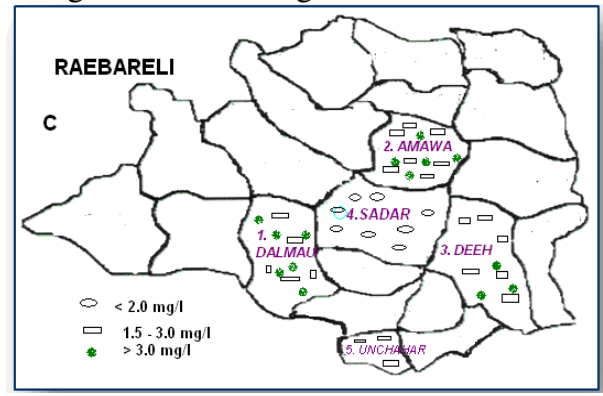

Figure 3. Fluoride affected blocks in Rae Bareli district 
Samples collected from all 5 blocks and their comparative fluoride level is shown in the following Table 6 .

Table 6. Sample collection and water fluoride level of selected blocks of Rae Bareli district

\begin{tabular}{|c|c|c|c|c|c|c|c|}
\hline 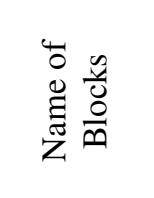 & 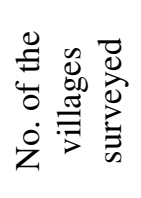 & 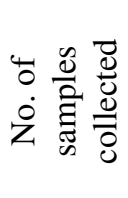 & 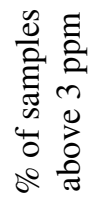 & 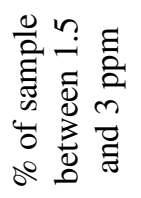 & 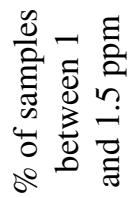 & 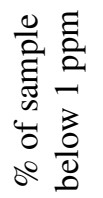 & 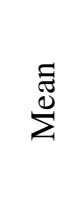 \\
\hline Dalmau & 10 & 30 & 20 & 70 & 10 & Nil & 2.34 \\
\hline Amawa & 10 & 30 & 13 & 53 & 27 & 7 & 1.94 \\
\hline Deeh & 4 & 12 & 16 & 34 & 17 & 33 & 1.87 \\
\hline Sadar & 8 & 24 & Nil & 4 & 38 & 55 & 0.92 \\
\hline Unchahar & 5 & 15 & Nil & 53 & 20 & 27 & 1.60 \\
\hline
\end{tabular}

Mapping of fluoride areas

Based on the results of fluoride level in groundwater samples, a fluoride isopleths map of the region was prepared. Fluoride zones containing high fluoride level in their groundwater were identified and distinguished by different symbols depicting the fluoride level shown in Figure 4. Google earth satellite images of exact location of fluoride endemic areas were prepared by using Google earth 4.3 betas.

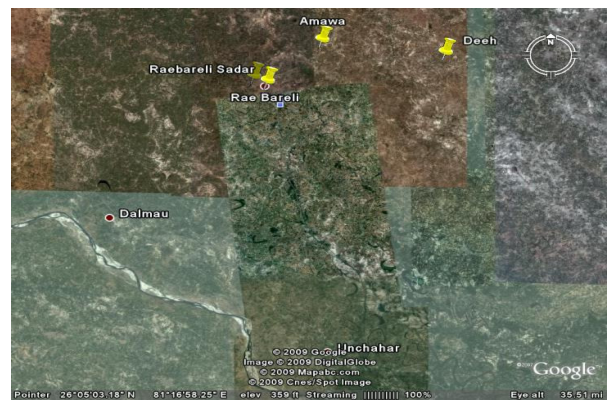

Figure 4. Location of fluoride endemic areas in Rae Bareli district

\section{Conclusion}

This study identified that $90 \%$ peoples of Dalmau block, $66 \%$ peoples of Amawa block and $50 \%$ peoples of Deeh block are fluoride affected. In Unchahar block 53\% villages have excess fluoride contamination in groundwater. Sadar block of Rae Bareli district has minimum $4 \%$ affliction of excess fluoride contamination. High fluoride level in groundwater in above block is due to geological formation. People of all age group are facing risk of fluorosis. The results could help the government of Uttar Pradesh to install defluoridation plants in severely affected villages identified by this study. Mapping bringing safe high fluorotic areas is useful to plan meticulously to bring safe groundwater from low fluoride areas.

\section{Acknowledgement}

Authors are thankful to the Head, Department of Chemistry, University of Allahabad, Allahabad for providing research facilities. 


\section{References}

1. Mason B H and Moore C B, Principles of geochemistry, $4^{\text {th }}$ Ed., Wiley, New York, 1987.

2. World Health Organization (WHO), International Standards for Drinking Water, $2^{\text {nd }}$ Ed., Geneva, 1963.

3. Indian Council of Medical Research (ICMR), Manual of Standards of Quality for Drinking Water, $2^{\text {nd }}$ Ed., India, 1975.

4. Ramesham V and Rajagopalan K J, J Geol Soc., 1985, 26, 125-132.

5. Suttie J W, J Agric Food Chem., 1969, 17(6), 1350-1352.

6. Jubb T F, Annand T E, Main D C and Murphy G M, Aust Vet J., 1993, 70(10), 379-383.

7. Schultheiss W A and Godley G A, J S Afr Vet Assoc., 1995, 66(2), 83-84.

8. Siddiqui A H, Br Med J., 1955, 2(4953), 1408-1413.

9. Ministry of health of the People's Republic of China, Method for determination of fluoride in drinking water of Endemic fluorosis areas, 1999.

10. Li Hai-rong, Liu Qing-bin, Wang Wu-yi, Yang Lin-sheng, Li Yong-hua and Feng Fujian, J Hazard Mater., 2009, 167(1-3), 892-895.

11. Teotia S P S and Teotia M, Ind J Environ Toxicol., 1991, 1(1), 1-16.

12. Susheela A K, Kumar A, Bhatnagar M and Bahadur R, Fluoride, 1993, 26, 97-104.

13. Karthikeyan G, Anitha P and Apparao B V, Fluoride, 1996, 29(3), 151-155.

14. Ekstrand J, Ehrnebo M and Boreus L O, Clin Pharmacol Ther., 1978, 23, 329-337.

15. Ekstrand J and Ehrnebo M, Eur J Clin Pharmacol., 1979, 16, 211-215.

16. Spak C J, Ekstrand J and Zylberstein D, Caries Res., 1982, 16, 249-256.

17. Ekstrand J, Hardell L I and Spak C J, Caries Res., 1984, 18, 87-92.

18. Rao G S, Annual Review of Nutrition, 1984, 4, 115-136.

19. Whitford G M, Basel Karger., 1996, 12-15(1), 46-58.

20. Susheela A K, Fluorosis Research and Rural Development Foundation, 2000.

21. Yu Y, Yang W and Dong Z, Chung Hua Liu Hsing Ping Hsueh Tsa Chih., 1996, 15, 257-259.

22. Shi J and Dai G, Chung Hua Liu Hsing Ping Hsueh Tsa Chih., 1990, 9, 10-12.

23. Chen Z, Liu W and Su G, Chin J Endemiol., 1990, 9, 345-346.

24. Li X S, Zhi J L and Gao R O, Fluoride, 1995, 28(4), 189-192.

25. Zhao L B, Liang G H, Zhang D N and Wu X R, Fluoride, 1996, 29(4), 190-192.

26. Xiang Q, Liang Y, Chen L, Wang C, Chen B, Chen X, Zhou M and Shanghai P R, Fluoride, 2003, 36(2), 84-94.

27. Mella S, Molina X and Atalah E, Rev Méd Chile., 1994, 122(11), 1263-1270.

28. Chinoy N J, Indian J Environ Toxicol., 1991, 1(1), 17-32.

29. Khaiwal R and Garg V K, Int J Environ Health Res., 2006, 16(2), 163-166. 